\title{
Leprosy and acquired factor VIII inhibitor: a case report
}

\author{
J M ANNICHINO-BIZZACCHI \& T F G S MACHADO \\ Department of Clinical Medicine, Hematology Section, School of \\ Medicine-UNICAMP, CP 6198, CEP 13081 Campinas, SP, \\ Brazil
}

Accepted for publication 4 January 1991

Summary In this report we describe a case of factor VIII inhibitor appearing in a man with leprosy, with comments on the clinical presentation of the disease, laboratory findings and outcome of the patient.

\section{Introduction}

A 76-year-old man with lepromatous leprosy was admitted to the hospital on 23 May 1986 with hematuria and ecchymoses. The patient had received DDS therapy for 27 years. There was no history of bleeding in the past and no family history of bleeding diathesis. The findings from coagulation studies (Tables 1 and 2) demonstrated the presence of an inhibitor of factor VIII. The screening for other autoantibodies, like ANF and RF, were negative. The treatment with DDS was promptly discontinued and substituted with clofazimine, and an infusion of cryoprecipitate was commenced, $50 \mathrm{U} / \mathrm{kg}$ every $12 \mathrm{hr}$. The prolonged activated partial thromboplastin time (APTT) was not corrected by the treatment, but there was a definite clinical improvement. Then azathioprine $(200 \mathrm{mg} /$ day $)$ and prednisone $(1 \mathrm{mg} / \mathrm{Kg} / \mathrm{d})$ were introduced, with the aim of reducing the patient's factor VIII inhibitor level. During the next year he had several skin ecchimoses and 13 months later he developed a large hematoma in the left hemithorax that required a transfusion of packed red blood cells. The plasma factor VIII activity was $7 \%$, his factor VIII inhibitor level did not change from its original value of $4 \mathrm{BU} / \mathrm{mL}$, and the medication was discontinued. The patient died 2 years later of heart failure, which was unrelated to the presence of the inhibitor.

\section{Laboratory investigation}

Activated Partial Thromboplastin Time (APTT) was measured with kaolin and human brain cephalin; ${ }^{1}$ factor VIII level by a described procedure; ${ }^{2}$ antifactor VIII inhibitor 
Table 1. Initial coagulation studies

\begin{tabular}{lcc}
\hline Test & Normal & Patient \\
\hline Platelet $/ \mathrm{mm}^{3}$ & $150-400 \times 10^{3}$ & $228 \times 10^{3}$ \\
Bleeding time, min & $2-6$ & 4 \\
Prothrombin time, sec & 12 & 13 \\
Thromboplastin time, sec & 41 & 71 \\
Factor VIII (\%) & $60-180$ & 8 \\
Factor IX (\%) & $60-200$ & 98 \\
\hline
\end{tabular}

Table 2. Inhibitor and factor VIII level

\begin{tabular}{lcc}
\hline Date & $\begin{array}{c}\text { Inhibitor titres } \\
\text { Bethesda units }\end{array}$ & $\begin{array}{c}\text { Factor VIII } \\
(\%)\end{array}$ \\
\hline $24 / 06 / 86$ & 5 & 8 \\
$15 / 07 / 86$ & 4 & 9 \\
$04 / 08 / 87$ & 5 & 7 \\
$06 / 09 / 88$ & 4 & 8 \\
\hline
\end{tabular}

assay by the Bethesda system $;^{3}$ and other tests were done using conventional methods.

Table 1 lists the initial studies performed on this patient and shows a factor VIII level of $3 \%$. Table 2 shows the factor VIII and inhibitor levels during the patient observation.

\section{Conclusions}

The spontaneous appearance of antibodies to factor VIII : $\mathrm{C}$ in nonhemophiliac patients is recognized as a rare but serious cause of hemorrhagic diathesis. ${ }^{4-7} \mathrm{It}$ is clinically distinct from inherited hemophilia, being characterized by few hemarthroses but frequent skin and other soft tissue hematomas. Acquired hemophilia is thought to be autoimmune, in which autoantibodies directed against the factor VIII molecule spontaneously develop for unknown reasons. It can occur in association with drugs, collagen vascular diseases, lymphoproliferative disorders, and the postpartum state, as well as in healthy persons. ${ }^{7-10}$

Although circulating anticoagulants have been described in lepromatous leprosy, ${ }^{11-13}$ for the first time this report finds that it was a factor VIII inhibitor. It is unlikely that sulphonamide was the cause of the production of factor VIII antibody, as in other cases of inhibitor associated with drugs, since the patient had used the medication for 27 years, with no side-effects. The erythema nodosum leprosum reaction has been associated with spontaneous reversible clotting abnormalities, ${ }^{14,15}$ but this patient has no sign of this complication. Therefore, maybe, there was a cause-and-effect relationship between the disease and the inhibitor, since leprosy patients, in particular lepromatous, have several immunological alterations, with increased titers of autoantibodies. ${ }^{16,17}$ However, in vitro studies, to confirm that the factor VIII inhibitor was indeed an antibody, were not carried out. 


\title{
References
}

1 Proctor PR, Rappaport SI. The partial thromboplastin time with kaolin. Am J Clin Pathol, 1961; 36: 212.

2 European Concerted Action on Thrombosis, Bulletin 2r. 2, Assay procedures, 1985.

3 Kasper CK, Aledort LM, Count RB et al. A more uniform measurement of factor VIII inhibitors (Letter). Thromb Diath Haemorrh, 1985; 34: 869.

4 Lottenberg R, Kentro TB, Kitchens CS. Acquired hemophilia. A natural history study of 16 patients with factor VIII inhibitors receiving little or no therapy. Arch Intern Med, 1987; 147: 1077.

5 Margoulis A Jr, Jackson DP, Ratnoff OD. Circulating anticoagulants: A study of 40 cases and a review of the literature. Medicine, 1961; 40: 202.

6 Bidwell E. Acquired inhibitors of coagulants. Ann Rev Med, 1969; 20: 63.

7 Green D, Lechner K. A survey of 215 non-hemophilic patients with inhibitors to factor VIII. Thromb Haemost, 1981; 45: 200.

${ }^{8}$ Reece EA, Fox HE, Rapapport F. Factor VIII inhibitors: a cause of severe postpartum hemorrhage. $A m J$ Obstet Gynecol, 1982; 144: 985.

9 Michiels JJ, Bosch LJ, van der Plas PM, Abels J. Factor VIII inhibitor postpartum. Scand J Haematol, 1978; 20: 79 .

10 Devereux S, Fisher DM, Roter BL, Hegde UM. Factor VIII inhibitor and raised platelet IgG levels associated with methyldopa therapy. Br J Haematol, 1983; 54: 485.

11 Muzellec Y, Carli P, Talard P, Pignon D, Chagnon A. Présence d'un anticoagulant circulant au cours d'une lèpre lépromateuse. Press Medical, 1989; 18: 938.

12 Cole FS, Brusch JL, Talarico L. A circulating anticoagulant in lepromatous leprosy. Int J Lepr, 1979; 47: 121.

13 Ness PM, Hymas PG, Gesme D, Perkins HA. A n unusual factor X inhibitor in leprosy. Am J Hematol, 1980; 8: 397.

14 Mukher jee A, Ghosh S. Some observations in lepra reaction. Bull Calcutta Sch Trop Med, 1971; 19: 57-9.

15 Mukher jee A, Ghosh S. Study of lepra reaction. Int J Lepr, 1974; 42: 143-9.

16 Yandava CN, Bhutani LK, Sharma AK, Nath I. Int J Lepr, 1989; 57: 633-40.

17 Rawlinson WD, Baston A, Hargrave JC. Clinical importance of changes in serum proteins, immunoglobulins and autoantibodies in leprosy. Int J Lepr, 1987; 55: 277-85.

\section{La lepre et l'inhibiteur acquis anti-VIII une observation}

\author{
J M Annichino-BizzacChi et T F G S MaChado
}

Sommaire Nous décrivons dans ce rapport un cas d'inhibiteur acquis anti-VIII chez un homme souffrant de la lèpre, avec commentaires sur les signes cliniques et biologiques de la maladie et l'évolution du patient.

\section{La lepra y el inhibidor factor VIII adquirido: un informe de caso}

\author{
J M Annichino-Bizzacchi y T F G S Machado
}

Resumen En este informe describimos un caso de inhibidor factor VIII que se presentó en un hombre con lepra, y comentarios sobre la presentación clínica de la enfermedad, los resultados de laboratorio y las consecuencias para el paciente. 